\title{
THE IMPACT OF EXTERNAL DEBT ON ECONOMIC GROWTH IN GHANA
}

\author{
Adubofour Isaac ${ }^{1 *}$, Mangudhla Tinashe ${ }^{2}$, Dadzie Benjamin Mensah ${ }^{3}$ \\ ${ }^{I}$ School of Finance and Economics, Jiangsu University, Zhenjiang, China \\ ${ }^{2}$ School of Management, University of Science and Technology of China, Hefei, China \\ ${ }^{3}$ Department of Computer Science and Mathematics, University of L'Aquila, Italy
}

*Correspondence Author: Adubofour Isaac.

Article DOI: $\underline{\text { https://doi.org/10.36713/epra8389 }}$

DOI No: 10.36713/epra8389

\begin{abstract}
The debt position of a country is crucial to the growth of its economy. We argue with empirical basis in this study that, external debt has impact on the growth of Ghana's economy. A time- series data, spanning from 1991-2019 was analyzed. The findings of the study suggested a statistically significant and inverse relationship between external debt and economic growth. It is also argued in the study that, Ghana's inflation regime has a significant impact on the growth of her economy. The study further verified the relationship between foreign direct investment and economic growth in Ghana. Results of the study revealed a significant and direct relationship between foreign direct investment in Ghana and the growth of the country's economy. A test on granger causality found no causal linkage between external debt and economic growth in Ghana. The contribution of the study was finally discussed and limitations stated to serve as a guide for future study.

KEYWORDS: External debt, economic growth, inflation, foreign direct investment, time series data.
\end{abstract}

\section{INTRODUCTION}

External debt is the component of a nation's debt borrowed from foreign creditors such as commercial banks, global financial institutions or governments. The borrowing nation is usually required to repay the loans received as well as the interest in the currency in which they acquired the loan(Kenton, 2020). A debt crisis may emerge if a country with a weak economy is not able to repay its external debt because of its inability to make profit via manufacturing and trading of goods. Economic growth refers to the surge in the production of economic goods and services over time. Usually, aggregate economic output is calculated in terms of either the gross national product (GNP) or gross domestic product (GDP), though alternative metrics are often employed. The question of external debt as a growth-friendly policy generates serious debate between economists and policymakers. The primary concern is as to whether external debt in debtor countries results in economic growth or not. The relationship between external debt and Economic Growth is often argued from these three perspectives: External debt is supplementary to domestic savings and investments, and therefore increases growth, researchers like (Ajayi \& Oke, 2012; Eaton \& Jonathan, 1993) claim. Krugman, (1988) has a different view on the fact that, servicing debts causes economic disruption and therefore dissuade investment and economic growth. After analyzing the effect of accumulated government debt on the Zambian economy, it was observed that government debt is a sword with two sides (Chongo, 2013).

However, given the "growth-debt" philosophy of a country's capacity to borrow externally, provided that the capital is insufficient to generate a rate of return that is greater than the sum of the foreign debt, it has generally been hoped that inadequate capital would be acquired by developing countries to supplement domestic savings and investments. The rates at which these countries borrow are dependent on the ties 
between domestic and foreign savings, investment and economic growth in order to increase borrowing countries' ability to produce foreign savings. However, external debt may be productive only if the debt is managed well to yield a return that is above the expense of servicing that debt. The increasing rate of Ghana's external debt profile has become a major concern into the future. In 2019, as part of Ghana's transformational agenda, the Ghanaian government borrowed 2 Billion US dollars from the Chinese government to fund its roads, rail and bridge networks in exchange for 5 percent of Ghana's bauxite reserve(Smith, 2019). Although external borrowing may be seen as the best way out of embarrassing economic circumstances, consistent borrowing accumulates overtime with an apparent significant economic implication for both the immediate and future generations' economies, being left with an extreme deterioration in living standards, a high external dependence, currency depreciation, total aggregate social and economic depreciation. Ghana's Foreign Debt from 1960 to 2019 averages to a total of \$ 6,581.80 million, reaching an all-time high of $\$ 26953.31$ million in Q4 2019. The increasing debt level of Ghana has consistently been associated with continued income shortfalls or overrunning perennial government spending(Amo-Yartey, 2014; Kusi, 2015; Kwakye, 2014).

The current global pandemic, popularly known as Covid-19 has also forced the country to increase her spending in the quest to mitigating the effect of the pandemic on the country. The country's debt-to-GDP is currently projected to reach $76.7 \%$ by December 2020 (IMF, 2020). Previous works on Ghana's debt level and its influence on the Ghanaian economy attributed Ghana's debt levels to persistent fiscal deficits of the Ghanaian government. Revenue targets or expenditure forecast shocks often force governments to finance their budget deficits through domestic or international borrowing. Given the growing foreign debt stock in Ghana, it is imperative for the country to undertake a critical review of the consequences of the accrued debt on its economic growth. Against this background have we decided to assess the exact level of impact of external debt on both the short and long runs on the economic growth of Ghana.

\section{REVIEW OF LITERATURE}

The inability of a country to raise adequate funds to meet its expenditure or basic needs leaves it no other choice than to look elsewhere, preferable to seek monetary assistance from foreign countries or institutions to meet its needs. A number of previous studies have suggested alternative ways by which governments of developing countries can raise funds for their economic developmental projects as well as measures to put in place to ensure sustainability of such debts. These literatures include: A. G. Awan and Qasim (2020)'s work that suggested that a country should generate funds through productivity, tax revenue and exports. A. G. Awan and Aslam (2015)'s study that resulted in a reasoning that, due to the fact that domestic debt can be paid in a borrowing country's own currency, it must be more preferred for a government of a country to borrow from domestic institutions or individuals rather than to borrow from external sources which usually puts the government under pressure or conditional ties in its usage and repayment.

Moreover, several studies in their attempt to analyze and measure the effect of external debt on a nation's economic growth via a plethora of methodologies have observed a negative whereas others have observed a positive relationship between external debt and economic growth and made suggestions based on their findings. Some of these literatures are the works of Ohiomu (2020) who employed the methodology of group unit root test, auto-regressive distributed lag (ARDL) bounds testing, and co-integrating long-run tests in his research to model external debt and economic growth nexus for policy analysis on public finance and public debt management. The result displayed inauspicious effect on the growth of the economy since the debt overhang and crowding-out effect decrease the level of investment in Nigeria. A Similar result was obtained when research conducted by Sajuyigbe et al. (2018) examined the impact of external debt on economic growth in Nigeria during the period of 1999 to 2015. The techniques of estimation employed in the study include Augmented Dickey Fuller (ADF) test, Johansen Co-integration, Vector Error Correction Mechanism and Granger Causality Test. Results show that external debt has an inverse effect on economic growth in Nigeria. Moh and Jaradat (2019) and Kharusi and Ada (2018) also supported this stance based on the results of their research in Jordan and Oman respectively, finding a significant and adverse impact of external debt on economic progress. Likewise, the study by Shkolnyk and Koilo (2018) examined between the period 2006 to 2016 the relationship between external debt and economic growth in emerging economies by taking into account ADL model, regression model and correlation analysis. Their findings suggest that high level of external debt, in conjunction with macroeconomic instability, hampers economic growth in such countries. Similar findings by Anderu and Omolade (2019) made them suggest in their study that external debt doesn't promote economic performance. (Awan \& Ghafoor, 2019) also based on a similar finding to conclude that 
developing countries are suffering poor governance and suggested that they should focus on improvement of the productivity to reduce the stock of foreign debt.

Furthermore, Shittu and Olawale (2018) found the same negative relationship between external debt and economic growth, with their analysis spanning from 1990 to 2015 and involving five Sub-Saharan African (SSA) countries. Pegkas (2018) addressed the issue of threshold effects in Greece between general government debt and economic growth for the period from 1970 to 2016 . Using threshold models, there is evidence in favor of a negative association between general government debt and economic growth. The results indicate that the magnitude of this negative relationship between debt and growth depends on debt regimes. Also, the results suggest that public debt is associated with lower growth at low and moderate public debt levels. It was further revealed that a positive impact of external debt on economic performance up to a threshold existed in N'Zue and Fofana (2020) research which assessed the impact of external debt on economic growth in the ECOWAS region using panel data crossing from 1990 to 2016 and analyzing with panel CS-ARDL estimation approach. Gövdeli (2019) ended up with the same positive impact of external debt on economic growth in the study he conducted. In addition, a cross-country study of developing economies of South Asia: Pakistan, Bangladesh, Sri-Lanka and India during the period of 1980 to 2014, Saeed and Islam (2018) used nonlinearity and endogeneity to examine the relationship between public debt and economic growth. The results showed an existence of a significant positive but nonlinear relationship between the public debt and economic growth for the selected set of developing countries.

However, a number of studies have investigated into the relationship between external debt and economic growth of a country and a group of countries in the perspective of the long and short terms. These studies includes that of Ehikioya and Omankhanlen (2020) in their study demonstrates that beyond a specific capacity, the short-run converges to equilibrium in the long-run and external debt would start to have a deteriorating impact on economic growth in Africa. Mazher and Dahalan (2019) determined that in short-run period, external debt to GDP have significant and negative relationship and for long-run period, the outcomes show that, external debt to GDP, ED to EE and IP to GDP ratios reveals negative and insignificant relationship with GDP. A study conducted by both Hameed and Quddus (2020) and Ahamad and Islam (2020) concluded that in both the short and longterm there exist an adverse effect of external debt on economic growth. Also, Zohaib (2020) show an inverse relation between external debt and economic growth in both short-term and long-term. Likewise, the findings of Ajayi and Ibidolapo (2020) which confirms the adverse effect in both short and long-term on the economic performance. The results from a study by Guei (2019) demonstrates that there is no robust effect of debt on economic growth in the long-term; nevertheless, in the short-term, there is a negative and significant correlation of external debt on economic growth. Edo and Osadolor (2020) adopted the ARDL panel model and appropriate estimation techniques to examine the influence of external debt and export on economic progress of Sub-Saharan African countries. Their findings revealed in the short-term, insignificant positive influence of both external debt and export on economic progress. Further on in the long-term, the influence turns negative.

Additionally, in the case of Ghana, specific studies upon attempting to analyze the long and short term influence of external debt and the growth of Ghanaian economy such as that of Asafo and Matuka (2019) who employed a co-integration analysis and an error correction methodology to examine the impact of external debt on economic growth in Ghana using annual time series for the period 1970 to 2017. Their conclusion is that external debt inflows spur growth in Ghana both in the long-run and short-run. They further confirmed the crowding out effect and the non-linear effect of external debt in the long run and short-run. However, Debt overhang was only confirmed in the short-run. Similarly, a study conducted by Matuka and Asafo (2018) using annual time series from 1970 to 2017 to research the effect of external debt on Ghana's economic growth using a co-integration analysis and error correction methodology. Their study revealed that in the short term and long term, external debt influxes cause growth in Ghana. Yusuf and Mohd (2020) analyzed public debt on economic growth for the period from 1980 to 2018. The empirical outcomes exhibited that external debt stock constituted an impediment to long-term growth but a short-run growth-enhancement effect. Other similar studies are that of (Anning \& Ofori, 2016); (Asiama \& Akosah, 2014); and (Frimpong \& Oteng-Abayie, 2006).

Despite the uniqueness in methodology and approach, these studies fell short in detailing and extensively looking into the exact long- and short-term impacts of external debt on the economic development of Ghana after taking into account controlled political factors. It is on this basis that this study aims to analyze the exact short-term and predict the long-term effects of external debt on Ghana's economic growth. To the best of our understanding, the methodology and the exactness approach of this study is first of its kind about Ghana and is expected to add up to the body of 
knowledge in the field of applied research as well as affect policy making decisions. This section is followed by a methodology, interpretation of data and presentation of the results. The research ends with analytical observations and provides recommendations in policy decision making to relevant stakeholders in Ghana.

\section{EMPIRICAL STRATEGY}

Most developing countries' demand for loans have increased astronomically since the emergence of the global pandemic, popularly known as Covid-19. The impact of such loans on the economy still remains hypothetical. An empirical approach is adopted, in an attempt to verify the impact of Ghana's external debt position on the growth of her economy.

\subsection{Data}

The data for this research was obtained from several sources, including the IMF, the WDI which is a database for the world bank, Ghana Statistical Service, as well as the central bank of Ghana. The study collected data on the external debt of Ghana, the real exchange rate, real GDP, gross capital formation, gross national savings, inflation, government expenditure, access to electricity, import and export of goods and services, and the country's labor force.

\subsection{Variable Description}

Table 1. Definition of studied variables.

Variable $\quad$ Description

Real Gross Domestic Product (RGDP) RGDP is a measure of a country's economic growth.

The data was obtained from the IMF database.

External Debt (EXTD)

External debt refers to debts that have foreign sources.

The debt will be expected to be paid back at an agreed period. This is our independent variable.

Exchange Rate (EXR)

The cedi-dollar exchange rate have impact on the country's trade position, which affects the economy in the long term. This variable is included in the model as explanatory variable.

Foreign Direct Investment (FDI)

This refers to foreign investment in a particular country.

Such investments have the capacity to affect the country's growth. This is added to the model as a control variable.

Gross Capital Formation (GCF)

This captures the number of fixed assets in a country as well as changes in inventories. This is controlled in. the model as explanatory variable.

Inflation (INF)

Inflation determines the pricing regime in a country. High inflation leads to high prices of goods and services.

It also increases the cost of borrowing and is detrimental to the growth of an economy. This is included in the model as a control variable.

Gross Savings (GS)

A country with high savings would have higher propensity to engage in investments that will lead to growth of the economy. This variable is included in the model as explanatory variable.

Government Expenditure (GOE) Capital expenditures expand growth of an economy. The consumption pattern of government would affect the growth of the economy. This is included in the model.

Labor Force (LF)

The labor force structure of a country has impact on her production capacity. A country with large active labor force would have higher ability to produce.

Import (IMP)

Export (EXP)

Access to electricity (ATE)

The country's total import of goods and services in the study period.

The total export of goods and services by the country. The total coverage of electric power by the country to citizens and the industrial sector. 


\subsection{Statement of Hypothesis}

Hypothesis are developed upon a critical assessment of past related literature. Previous studies that analyzed the interplay between a country's external debt and economic growth are critically examined. The study primarily seeks to establish the relationship between Ghana's external debt and her economic growth. The search would be extended to ascertaining the association between inflation and economic growth in Ghana.

Main hypothesis:

Hypothesis 1: External debt has inverse relation with the growth of Ghana's economy. This hypothesis is developed on the grounds that, a country's economic growth position declines as it increases its borrowing externally. This was stated after analyzing past studies that suggested a decrease in real GDP as external debt increases (Shkolnyk and Koilo (2018); Zohaib (2020).

Other hypotheses:

Hypothesis 2: Inflation has inverse relation with economic growth in Ghana. We hypothesized that, high inflation in the country would lead to a decreased growth. This means that, growth in the economy declines as the cost of borrowing increases due to the rise in inflation.

Hypothesis 3: FDI has positive association with economic growth in Ghana. This hypothesis is stated on the assumption that, as the country receives more foreign investment, her economic growth will increase.

\subsection{Model}

With the aim at verifying the interplay between external debt and Ghana's economic growth, an econometric technique is employed. The Prais-Winsten Regression technique would be employed in the empirical analysis so as to examine the statistical relationship between Ghana's foreign debt and the growth of her economy.

$\log (\mathrm{RGDP})=\beta_{0}+\beta_{1} \log (\mathrm{EXTD})+\beta_{2} \log (\mathrm{EXR})$ $+\beta_{3} \log (\mathrm{FDI})+\beta_{4} \log (\mathrm{GCF})+\beta_{5} \log (\mathrm{INF})+\beta_{6} \log (\mathrm{GS})$ $+\beta_{7} \log (\mathrm{GOE})+\beta_{8} \log (\mathrm{LF})+\beta_{9} \log (\mathrm{IMP})+$ $\beta_{10} \log (\mathrm{EXP})+\beta_{11} \log (\mathrm{ATE})+\boldsymbol{\varepsilon}$

A number of control variables are included in the model, so as to cater for possible endogeneity, as previously argued by Wooldridge, 2010. All variables are transformed using logarithms. $\beta_{0}$ indicates the model's intercept whilst $\beta_{1}-\beta_{8}$ shows the slope of the model.

\section{RESULTS}

Table 2 provides a summary statistic on the variables. The table presents external debt as the variable with the highest mean value (8.692) whilst showing FDI as the variable with the lowest mean value (-1.187). Table 2 also reports FDI as the variable with the largest deviation from its mean (0.924) whilst capturing labor force as the variable with the least deviation from its mean (0.054). The table also captures FDI as the variable with the minimum value $(-2.975)$ whilst capturing external debt as the variable with the highest value (9.425).

Table 3 presents results on correlation between the studied variables. It shows that most of the variables have low bivariate correlations. It presents the correlation between exchange rate and access to electricity as the highest (0.966), showing a strong positive correlation. It also captures the correlation between real GDP and gross capital formation as the weakest (-0.526).

Table 2. Descriptive Statistics. The table below presents a summary statistic on the studied variables (1991-2019).

\begin{tabular}{llllcccc}
\hline Variable & Median & Mean & Std. Dev. & Min. & $25^{\text {th }} \%$ & $75^{\text {th }} \%$ & Max \\
\hline RGDP (log transformed) & 0.685 & 0.712 & 0.170 & 0.338 & 0.614 & 0.806 & 1.148 \\
EXTD (log transformed) & 8.608 & 8.692 & 0.296 & 8.347 & 8.489 & 8.765 & 9.425 \\
EXR (log transformed) & -0.043 & -0.160 & 0.622 & -1.432 & -0.636 & 0.254 & 0.691 \\
FDI (log transformed) & -1.543 & -1.187 & 0.924 & -2.975 & -1.272 & -0.971 & 1.623 \\
GCF (log transformed) & 1.332 & 1.315 & 0.114 & 1.107 & 1.217 & 1.395 & 1.478 \\
INF (log transformed) & 1.190 & 1.222 & 0.214 & 0.853 & 1.067 & 1.396 & 1.774 \\
GS (log transformed) & 1.026 & 1.143 & 0.246 & 0.598 & 1.026 & 1.330 & 1.405 \\
IMP (log transformed) & 0.409 & 0.378 & 0.099 & 0.207 & 0.335 & 0.446 & 0.524 \\
EXP (log transformed) & 1.505 & 1.466 & 0.141 & 1.230 & 1.398 & 1.562 & 1.688 \\
ATE (log transformed) & 1.738 & 1.706 & 0.149 & 1.325 & 1.628 & 1.808 & 1.899 \\
GOE (log transformed) & 0.099 & 0.046 & 0.109 & -0.223 & 0.011 & 0.124 & 0.148 \\
LF $(\log$ transformed) & 1.873 & 1.861 & 0.054 & 1.756 & 1.849 & 1.884 & 1.983 \\
\hline
\end{tabular}


Table 3. Correlation between variables

\begin{tabular}{|c|c|c|c|c|c|c|c|c|c|c|c|}
\hline Variable & RGDP & EXTD & EXR & FDI & $\overline{\text { GCF }}$ & INF & GOE & LF & IMP I & EXP & ATE \\
\hline RGDP & 1.000 & & & & & & & & & & \\
\hline EXTD & -0.050 & 1.000 & & & & & & & & & \\
\hline EXR & 0.252 & 0.546 & 1.000 & & & & & & & & \\
\hline FDI & -0.283 & 0.082 & -0.052 & 1.000 & & & & & & & \\
\hline GCF & -0.526 & 0.183 & 0.122 & 0.229 & 1.000 & & & & & & \\
\hline INF & -0.474 & -0.094 & -0.412 & 0.194 & 0.369 & 1.000 & & & & & \\
\hline GS & -0.524 & 0.467 & 0.165 & 0.129 & 0.734 & 0.369 & 1.000 & & & & \\
\hline GOE & -0.556 & 0.440 & 0.106 & 0.145 & 0.725 & 0.421 & 0.995 & 1.000 & & & \\
\hline LF & -0.030 & -0.315 & -0.284 & -0.005 & 0.141 & -0.083 & 0.020 & 0.058 & 1.000 & & \\
\hline IMP & 0.185 & 0.252 & 0.667 & 0.465 & 0.218 & -0.303 & 0.134 & 0.097 & -0.137 & 1.000 & \\
\hline EXP & 0.177 & 0.242 & 0.646 & 0.470 & 0.219 & -0.284 & 0.141 & 0.105 & -0.135 & 0.999 & 1.000 \\
\hline ATE & 0.257 & 0.460 & 0.966 & -0.131 & 0.131 & -0.457 & 0.055 & -0.003 & -0.262 & 20.596 & $\begin{array}{lll}6 & 0.570 & 1.000\end{array}$ \\
\hline
\end{tabular}

\subsection{Preliminary Tests on Studied variables}

- Augmented Dickey Fuller Test

$H_{0}$ : variables are non-stationary

$H_{1}$ : variables are stationary
The ADF test in table 4 below shows that, most of the variables are non-stationary except gross capital formation and inflation.

Table 4. ADF

\begin{tabular}{lclll}
\hline Variable & L1 & Constant & Trend & t-statistic \\
\hline RGDP & -0.650 & 0.406 & 0.004 & $-3.003^{* *}$ \\
EXTD & -0.072 & 0.574 & 0.006 & $-0.603^{* *}$ \\
EXR & -0.218 & -0.156 & 0.012 & $-2.551^{* *}$ \\
FDI & -0.556 & -0.341 & -0.019 & $-2.502^{* *}$ \\
GCF & -0.591 & 0.811 & -0.002 & -3.791 \\
INF & -0.817 & 1.214 & -0.014 & -3.837 \\
GS & -0.393 & 0.474 & -0.001 & $-2.234^{* *}$ \\
GOE & -0.413 & 0.032 & -0.000 & $-2.281^{* *}$ \\
LF & -0.985 & 1.865 & -0.002 & $-3.367^{* *}$ \\
IMP & -0.277 & 0.104 & 0.001 & $-1.999^{* *}$ \\
EXP & -0.281 & 0.412 & 0.001 & $-2.006^{* *}$ \\
ATE & -0.224 & 0.373 & 0.002 & $-1.124^{* *}$ \\
\hline SO & &
\end{tabular}

Source: Author's calculation. ${ }^{* * *},{ }^{* *}$ and ${ }^{*}$ indicate significance at $1 \%, 5 \%$ and $10 \%$ levels respectively.

- $\quad$ Philips-Perron (PP) Unit Root test

$H_{0}$ : variables are non-stationary

$H_{1}$ : variables are stationary

Results from the PP test for unit root in table 5 below indicates a non-stationarity of most of the variables under study with the exception of labor force and access to electricity.

Table 5. PP Test

\begin{tabular}{lcccl}
\hline Variable & L1 & Constant & Trend & t-statistic \\
\hline RGDP & 0.433 & 0.342 & 0.004 & $-3.172^{* *}$ \\
EXTD & 0.890 & 0.908 & 0.005 & $-1.130^{* *}$ \\
FDI & 0.429 & -0.449 & -0.014 & $-3.148^{* *}$ \\
GCF & 0.617 & 0.523 & -0.001 & $-2.509^{* *}$ \\
INF & 0.364 & 0.898 & -0.008 & $-3.220^{* *}$ \\
GS & 0.636 & 0.401 & 0.002 & $-2.392^{* *}$ \\
GOE & 0.619 & 0.013 & 0.000 & $-2.427^{* *}$ \\
LF & 0.025 & 1.842 & -0.002 & -4.762 \\
IMP & 0.755 & 0.090 & 0.001 & $-2.006^{* *}$ \\
EXP & 0.750 & 0.364 & 0.001 & $-2.029^{* *}$ \\
ATE & 0.481 & 0.797 & 0.007 & -3.983
\end{tabular}

Source: Author's calculation. ${ }^{* * *},{ }^{* *}$ and $*$ indicate significance at $1 \%, 5 \%$ and $10 \%$ levels respectively. 
- Granger causality test

Relationship is different from causality. Regression analysis shows relationship between studied variables but does not establish causality. The foundation of granger causality test is built on the assumption that, if event $\mathrm{A}$ happens before event $\mathrm{B}$, then it can be postulated that, A causes B. That is, past

These can be specified as:

$E X T D_{t}=\Sigma \alpha 1 n i=1 R G D P_{t}-i+\Sigma \beta 1 n i=1 E X T D_{t}-j+\mu 1_{t}$ $R G D P_{t}=\Sigma \lambda 1 n i=1 R G D P_{t}-1+\Sigma \delta 1 n i=1 E X T D_{t}-j+\mu 2_{t}$

It is assumed that the disturbance terms $\mu 1_{t}$ and $\mu 2_{t}$ do not correlate. The two variables in the equation $\left(E X T D_{t}\right.$ and $\left.R G D P_{t}\right)$, signify bilateral causality. The Vector Auto Regression (VAR) approach can be adopted since the equations deal with bilateral causality.

Results from the granger causality test found no causality among most of the variables. However, a unidirectional causality was found among some of the event causes present events, future events cannot (Gujurati and Sangeetha, 2007). By considering an equation of $R G D P_{t}$, a function of $E X T D_{t}$, in an attempt to establish if $E X T D_{t}$ causes $R G D P_{t},\left(E X T D_{t} \rightarrow R G D P_{t}\right)$ or if $R G D P_{t}$ causes $E X T D_{t}\left(R G D P_{t} \rightarrow E X T D_{t}\right)$. The arrow shows the causal direction.

variables. A unidirectional causality was found between gross capital formation and real GDP. A unidirectional causality was also established between labor force and real GDP. A unidirectional causality was finally found between real GDP (a proxy for measuring economic growth) and access to electricity. The test established no causal linkage between all other variables and economic growth.

Table 6. Granger causality test

\begin{tabular}{lccl}
\hline Null hypotheses & F-statistics & P-values & Decision \\
\hline Lagged $E X T D_{t}$ does not cause $R G D P_{t}$ & 0.243 & 0.786 & Do not reject \\
Lagged $R G D P_{t}$ does not cause $E X T D_{t}$ & 0.090 & 0.914 & Do not reject \\
Lagged $F D I_{t}$ does not granger cause $R G D P_{t}$ & 0.294 & 0.748 & Do not reject \\
Lagged $R G D P_{t}$ does not granger cause $F D I_{t}$ & 0.833 & 0.448 & Do not reject \\
Lagged $G C F_{t}$ does not granger cause $R G D P_{t}$ & 5.380 & 0.013 & Reject \\
Lagged $R G D P_{t}$ does not granger cause $G C F_{t}$ & 1.813 & 0.187 & Do not reject \\
Lagged $I N F_{t}$ does not granger cause $R G D P_{t}$ & 1.475 & 0.251 & Do not reject \\
Lagged $R G D P_{t}$ does not granger cause $I N F_{t}$ & 2.185 & 0.136 & Do not reject \\
Lagged $G S_{t}$ does not granger cause $R G D P_{t}$ & 2.301 & 0.124 & Do not reject \\
Lagged $R G D P_{t}$ does not granger cause $G S_{t}$ & 0.104 & 0.902 & Do not reject \\
Lagged $G O E_{t}$ does not granger cause $R G D P_{t}$ & 1.976 & 0.163 & Do not reject \\
Lagged $R G D P_{t}$ does not granger cause $G O E_{t}$ & 0.123 & 0.885 & Do not reject \\
Lagged $L F_{t}$ does not granger cause $R G D P_{t}$ & 2.983 & 0.071 & reject \\
Lagged $R G D P_{t}$ does not granger cause $L F_{t}$ & 2.037 & 0.154 & Do not reject \\
Lagged $I M P_{t}$ does not granger cause $R G D P_{t}$ & 0.757 & 0.481 & Do not reject \\
Lagged $R G D P_{t}$ does not granger cause $I M P_{t}$ & 0.866 & 0.434 & Do not reject \\
Lagged $E X P_{t}$ does not granger cause $R G D P_{t}$ & 0.754 & 0.482 & Do not reject \\
Lagged $R G D P_{t}$ does not granger cause $E X P_{t}$ & 0.904 & 0.419 & Do not reject \\
Lagged $A T E_{t}$ does not granger cause $R G D P_{t}$ & 0.421 & 0.662 & Do not reject \\
Lagged $R G D P_{t}$ does not granger cause $A T E_{t}$ & 3.563 & 0.046 & reject \\
\hline
\end{tabular}

\subsection{Regression results}

The Prais-Winsten regression technique was adopted as an econometric technique for the empirical analysis, in the attempt to verify the impact of external debt on economic growth in Ghana. The result is presented in Table 7 below.

Findings of the study revealed a statistically significant and inverse relation between external debt and Ghana's economic growth $(\beta=-0.158, p<0.1)$. This strongly supports hypothesis 1 . This means that, an increase in the country's foreign debt would result in a decline in the growth of the economy. The result is consistent with the findings of previous study Zohaib (2020). The study also found a statistically significant and negative association between inflation and economic growth in Ghana. This means that, high inflation in the economy impedes on economic growth. This is in support of hypothesis 2 .

Findings of the study also suggested a statistically significant relationship between foreign direct 
investment and economic growth in Ghana. It was established that, an increase in FDI would lead to a corresponding increase in the growth of the economy. This also supports hypothesis 3 . The study also found a statistically significant relationship between other some control variables and economic growth in Ghana. It was found that, an increase in the price of the US dollar against the Ghanaian cedi would lead to a rise in growth rate in Ghana. The study also observed improvement in the economy as government reduces its consumption expenditure. The research found that, an increase in the country's export volumes would result in a rise in economic growth. It was further established that, access to electric power increases growth of the economy as production increases.

Table 7. Regression Results

\begin{tabular}{llccl}
\hline Variable & Coefficient & Std. Error & t-statistic & P-values \\
\hline EXTD & -0.158 & 0.134 & 1.180 & $0.056^{*}$ \\
EXR & 0.117 & 0.263 & 0.450 & $0.061^{*}$ \\
FDI & 0.128 & 0.052 & -2.470 & $0.025 * *$ \\
GCF & -0.341 & 0.483 & -0.700 & 0.490 \\
INF & -0.145 & 0.190 & -0.770 & $0.054^{*}$ \\
GS & 1.889 & 1.397 & 1.350 & 0.194 \\
GOE & -5.104 & 3.018 & -1.690 & $0.019^{* *}$ \\
LF & 0.608 & 0.558 & 1.090 & 0.291 \\
IMP & 1.477 & 1.878 & 1.650 & 0.118 \\
EXP & 1.634 & 0.795 & 1.050 & $0.013^{* *}$ \\
ATE & 1.364 & 1.081 & 1.270 & $0.022^{* *}$ \\
Cons. & 9.896 & 7.863 & 1.260 & 0.225 \\
\hline$R^{2}=0.649$ & ADJ. $R^{2}=0.421$ & F-Stat $(11,17)=2.85 \quad$ DW $=1.889$ \\
Source: Author's calculation. $* * *, * *$ and * indicate significance at $1 \%, 5 \%$ and $10 \%$ levels respectively.
\end{tabular}

\section{CONCLUSION AND DISCUSSION}

The study identified a statistically significant and inverse relation between Ghana's external debt position and the growth of her economy in an attempt to verify the impact of external debt on economic growth in Ghana. This means that, the growth of Ghana's economy declines when the government borrows more, externally. Findings of the study also revealed a statistically significant and negative correlation between inflation and economic growth. This means that, a rise in the rate of inflation in the economy results in a decline of the growth of the economy.

A further verification indicated a significant relationship between foreign direct investment and economic growth in Ghana. Results of the study suggested an increase in the growth of the economy as FDI increases. Findings from the granger causality test found no causal linkage between external debt and economic growth in Ghana. The results however, revealed a unidirectional causality between gross capital formation and economic growth in Ghana. A unidirectional causality was also identified between labor force and growth of the economy, suggesting that, the country's labor force could cause a growth of the economy. Results from the test finally identified a unidirectional relationship between economic growth and the access to electric power in the country.

\subsection{Theoretical Contributions}

The study makes significant theoretical contribution to the study of external debt and economic growth. The government would have to consider its external borrowing decisions as well as its debt financing regime since the country's debt position has impact on the growth of the economy. The research contributes to the few existing literature that underscored the interaction between external debt and economic growth (Anning et al., 2016 ; Asafo and Matuka (2019).

The research was extended to identifying the relationship between inflation and growth of the economy. The study admonishes policy decision makers to fully regard the economic position of macroeconomic variables so as to enhance growth of the economy since inflation showed to be a significant factor of the economy's growth.

The study also makes an important theoretical contribution to the study of foreign direct investment and economic growth. The government is expected to create enabling environment that would trigger foreign investment in the country. The study advances the knowledge in literature regarding the interplay between FDI and economic growth.

\subsection{Limitations and Future research}

The study faced the problem of the availability of data in its attempt to empirically ascertain the impact of 
foreign debt on Ghana's economy. Future studies in admonished to expand the scope of the variables if data is available. All other relevant variables that may have the capacity to influence the growth of Ghana's economy should be included in future study.

Although external debt showed to be a significant factor of growth of the economy, other covariate and external factors may also have the propensity to influence growth of the economy. future researchers are therefore encouraged to consider factors such as government policy decisions in their analysis.

\section{REFERENCES}

1. Ahamad, K. M. U., \& Islam, M. M. (2020). The Effects of Public Debt on Economic Growth in Bangladesh: An Evidence from the ARDL Bound Testing Approach. International Journal of Economics Financial Research, 6(5), 87-95.

2. Ajayi, \& Ibidolapo. (2020). EFFECT OF PUBLIC DEBT ON ECONOMIC GROWTH OF NIGERIA: AN EMPIRICAL INVESTIGATION.

3. Ajayi, \& Oke, B. (2012). Effect of external debt on economic growth and development of Nigeria. 3(12), 297-304.

4. Amo-Yartey, C. J. T. I. o. E. A. G. (2014). Improving fiscal management in ghana: the role of fiscal policy rules.

5. Anderu, \& Omolade. (2019). External debt and economic growth in Nigeria. Journal of African Union Studies, 8(3), 157.

6. Anning, \& Ofori. (2016). The impact of government debt on the economic growth of Ghana: A time series analysis from 1990-2015. 2(5), 31-39.

7. Asafo, S. S., \& Matuka, A. (2019). EXTERNAL DEBT AND ECONOMIC GROWTH IN GHANA: A CO-INTEGRATION AND VECTOR ERROR CORRECTION ANALYSIS. Theoretical Practical Research in Economic Fields, $10(1$ (19)), 45-53.

8. Asiama, \& Akosah. (2014). An assessment of fiscal sustainability in Ghana.

9. Awan, \& Ghafoor. (2019). Causes of Trade deficit and its impact on Pakistan's Economic growth. 5(3), 480-498.

10. Awan, A. G., \& Aslam, A. (2015). Impact of agriculture productivity on economic growth: A case study of Pakistan. Global Journal of Management Social Sciences, 1(1), 57-71.

11. Awan, A. G., \& Qasim, H. (2020). The impact of external debt on Economic Growth of Pakistan. Global Journal of Management, Social Scienes Humanities, 6(1), 30-61.

12. Chongo, M. B. (2013). An econometric analysis of the impact of public debt on economic growth: The case of Zambia.

13. Eaton, \& Jonathan. (1993). Sovereign debt: A primer. 7(2), 137-172.

14. Edo, \& Osadolor. (2020). Growing external debt and declining export: The concurrent impediments in economic growth of Sub-Saharan African countries. International Economics, 161, 173-187.
15. Ehikioya, \& Omankhanlen. (2020). Dynamic Relations Between Public External Debt and Economic Growth in African Countries: A Curse or Blessing? Journal of Open Innovation: Technology, Market, Complexity, 6(3), 88.

16. Frimpong, \& Oteng-Abayie. (2006). The impact of external debt on economic growth in Ghana: a cointegration analysis. 26(3), 122-131.

17. Gövdeli, T. (2019). External Debt and Economic Growth in Turkey: An Empirical Analysis. Sosyoekonomi, 27.

18. Guei, K. (2019). External debt and growth in emerging economies. International Economic Journal, 33(2), 236-251.

19. Hameed, M. R., \& Quddus, M. A. (2020). Impact of High and Growing Public Debt on Economic Growth in SAARC Countries: An Econometric Analysis. Journal of Political Studies, 27(1), 125142.

20. IMF. (2020, 1st September, 2020). World Development Indicators.

21. Kenton, W. (2020, May 9, 2020). External Debt Defined. Retrieved from https://www.investopedia.com/terms/elexternaldebt.asp

22. Kharusi, S. A., \& Ada, M. S. (2018). External debt and economic growth: The case of emerging economy. Journal of economic integration, 33(1), 1141-1157.

23. Krugman, P. R. (1988). Financing vs. forgiving a debt overhang (0898-2937). Retrieved from

24. Kusi, N. K. J. I. f. (2015). Ghana: Recent Fiscal Challenges and Risks: What Should We Expect in 2016?

25. Kwakye, J. K. (2014). Budget Discipline Should Be Entrenched In Ghana As A Policy Priority.

26. Matuka, A., \& Asafo, S. S. (2018). External debt and economic growth in Ghana: A co-integration and a vector error correction analysis.

27. Mazher, M. A., \& Dahalan, D. J. (2019). EFFECTS OF EXTERNAL DEBT, INTEREST PAYMENTS AND EXPORT EARNINGS FOR ECONOMIC GROWTH OF PAKISTAN. International Research Journal of Marketing Economics., 6(3), 16-31.

28. Ministry of Trade and Industry (2018). 'Ghana's Exports, Imports and Trade Partners'.

29. Moh, K. A., \& Jaradat, M. S. (2019). Impact of external debt on economic growth in Jordan for the period (2010-2017). International Journal of Economics Finance, 11(4), 104-113.

30. N'Zue, \& Fofana. (2020). Is External Debt Hampering Growth in the ECOWAS Region? International Journal of Economics Finance, 12(4).

31. Ohiomu, S. (2020). External Debt and Economic Growth Nexus: Empirical Evidence From Nigeria. The American Economist, 0569434520914862.

32. Pegkas, P. (2018). Government debt and economic growth. A threshold analysis for Greece. Peace Economics, Peace Science Public Policy, 25(1).

33. Saeed, S., \& Islam, T. (2018). Public Debt and Economic Growth Nexus: Evidence from South Asia. 
34. Sajuyigbe, Ademola, Odetayo, Tajudeen, Adeyemi, \& Adewumi. (2018). External debt and economic growth of Nigeria: An empirical investigation. South Asian Journal of Social Studies Economics, $1-11$.

35. Shittu, \& Olawale. (2018). The nexus between external debt, corruption and economic growth: evidence from five SSA countries. African Journal of Economic Management Studies.

36. Shkolnyk, I., \& Koilo, V. (2018). The relationship between external debt and economic growth: Empirical evidence from Ukraine and other emerging economies. Investment Management Financial Innovations, 15(1).

37. Smith, E. (2019). China's $\$ 2$ billion deal with Ghana sparks fears over debt, influence and the environment. Retrieved from https://www.cnbc.com/2019/11/21/chinas-2-billionghana-deal-fears-over-debt-influenceenvironment.html.

38. Yusuf, \& Mohd. (2020). The Impact of Government Debt on Economic Growth in Nigeria.

39. Zohaib, M. (2020). Public Debt and Economic Growth: An Empirical Evidence from Pakistan.

40. Wooldridge, J. M. (2010). Econometric Analysis of Cross Section and Panel Data. Cambridge, MA: MIT Press.

41. World Bank (2020). World Development Indicators. http://data.worldbank.org/data catalog/world developmentindicators. 